\title{
Investigation of the safe withdrawal period for propranolol in patients scheduled for open heart surgery
}

\author{
D. John Coltart, * Mitchell N. Cayen, Edward B. Stinson, Robert H. Goldman, \\ Richard O. Davies, and Donald C. Harrison \\ From the Division of Cardiology and the Department of Surgery, Stanford University School of Medicine, \\ Stanford, California; and Ayerst Laboratories, Montreal, Canada
}

The time necessary for dissipation of radioactive labelled propranolol and its metabolites and the cardiac effects of this agent in the hearts of patients undergoing open-heart surgery were studied. Isoprenaline produced chronotropic and inotropic responses in atrial muscle in tissue bath studies which were normal 8 to $I 2$ hours after withdrawing propranolol. After the administration of either 25 or $75 \mu \mathrm{Ci}$ of ${ }^{14} \mathrm{C}$-labelled propranolol, the myocardial tissue concentration declined to insignificant levels between 24 and 28 hours. We conclude that withdrawal of propranolol therapy 24 to 48 hours before cardiac surgery should be acceptable.

Propranolol is widely used in clinical practice for the treatment of ischaemic heart disease, cardiac arrhythmias, hypertrophic cardiomyopathy, hypertension, thyrotoxicosis, anxiety disorder, etc. Sometimes patients receiving drugs for these conditions may require surgery for other unrelated emergencies. Moreover, indications for cardiac surgery may develop in patients with ischaemic heart diseases who are receiving propranolol.

Because of its propensity to attenuate sympathetic responses during operation, it may be desirable to discontinue propranolol at some time before anaesthesia. A report from the Cleveland Clinic (Viljoen, Estafanous, and Kellner, 1972) described five patients who had been receiving propranolol for symptomatic relief of angina pectoris and who failed to survive coronary artery bypass surgery. The prior use of the drug was incriminated in the immediate postoperative complications, and the authors recommend that propranolol be withheld for two weeks before operation, commenting that it

Received 13 March 1975.

Presented in part at the 46th Scientific Sessions of the American Heart Association, Atlantic City, New Jersey, November, I973.

This work was supported in part by NIH Grants Nos. HL5709 and HL-5866. Dr. Coltart was supported in part by grants from the Peel Medical Research Trust and the Lilly International Fellowship Plan.

^ Present address: St. Thomas's Hospital, London SEI ${ }_{7} E H$, England. is unlikely that ischaemic heart disease would progress as the result of withdrawing the drug for this period of time. However, it may not be possible or necessary to withhold surgery for such a long period of time in patients receiving propranolol and in whom it is desired to stop the drug before surgery, since the drug has a serum half-life of only 3 to 6 hours (Shand and Rangno, 1972).

In this study we present data on the residual in vitro pharmacological activity remaining in atria taken from cardiac patients who receive propranolol chronically, and information on the in vivo decay pattern of propranolol's chronotropic and inotropic activity in patients in whom serum and tissue levels were also determined after administration of ${ }^{14} \mathrm{C}$ labelled propranolol. A study of concomitant pharmacological and drug metabolic residuals may assist in further defining the interval necessary for withdrawal of the drug before surgery.

\section{Methods}

Beta blockade was assessed in vitro in human atria and in vivo in patients before anaesthesia using noninvasive techniques. Serum levels and tissue residual concentrations of propranolol were determined following ${ }^{14} \mathrm{C}$ labelled propranolol administration using biochemical techniques (Coltart and Shand, 1970).

Patients studied

Group 1A and B (control and chronic preoperative oral 
propranolol patients).-Atrial and plasma samples were obtained during coronary artery bypass surgery in four patients who had not received propranolol (A), and in four in whom chronic propranolol treatment $(80 \mathrm{mg}$ six-hourly) had been discontinued for 24 to 72 hours preoperatively (B). The atrial tissue was examined for pharmacological activity by in vitro isoprenaline challenge (see below).

Group 2 (acute preoperative intravenous radioactive propranolol). In four patients undergoing mitral valve replacement a single dose of $\mathrm{Img}{ }^{14} \mathrm{C}$-labelled propranolol $(25 \mu \mathrm{Ci})$ was administered intravenously 4 to I $\frac{1}{2}$ hours before surgery. Serial plasma samples were taken and tissue was obtained during operation from skeletal muscle (rectus abdominis), adipose tissue, and right atrial and left ventricular papillary muscle sites.

Group $3 A$ and $B$ (acute peroperative oral radioactive propranolol) In four patients undergoing mitral valve replacement $4 \mathrm{I} \mathrm{mg}$ of ${ }^{14} \mathrm{C}$-labelled propranolol $(25 \mu \mathrm{Ci})$ was administered orally 24 to 96 hours before surgery (A). In a further two patients (B) $43 \mathrm{mg}$ of ${ }^{14} \mathrm{C}$-labelled propranolol $(75 \mu \mathrm{Ci})$ was given orally 28 to 29 hours preoperatively. Samples were taken as in Group 2 patients.

\section{Pharmacological studies}

In vitro Atrial tissue specimens from patients in Groups IA and IB were prepared as previously described (Coltart and Spilker, 1972), and an in vitro dosecontractility response curve to varying concentrations of isoprenaline was determined from patients (Group IB) who had been on chronic propranolol therapy and from control patients (Group IA). These studies were carried out in a muscle bath at $37^{\circ} \mathrm{C}$ by standard isometric techniques (Coltart and Spilker, 1972).

In vivo In two patients from each of Groups 2, $3 \mathrm{~A}$, and $3 \mathrm{~B}$ the degree of beta blockade was determined according to Cleaveland, Rangno, and Shand (1972) by estimating the dose of bolus injections of isoprenaline required to increase the resting heart rate by 25 beats/ min. Systolic time interval changes in response to isoprenaline were also measured, and the dose required to shorten the pre-ejection phase (PEP) by $50 \mathrm{~ms}$ was determined (Weissler, Harris, and Schoenfeld, 1968). These isoprenaline challenges were performed prior to and at 30-min intervals after administration of oral or intravenous propranolol.

\section{Biochemical and radioactivity measurements}

Plasma levels Plasma propranolol levels were measured by a modification (M. Kraml, in preparation) of the fluorometric procedure of Shand, Nuckolls, and Oates (1970). The sensitivity of the method was ro $\mathrm{ng} / \mathrm{ml}$ ( $2 \mathrm{ml}$ of plasma was assayed). In order to improve the sensitivity of the plasma propranolol measurement in patients treated intravenously with $1 \mathrm{mg}{ }^{14} \mathrm{C}$-labelled propranolol the radioactivity content of the final $\mathrm{HCl}$ solution (i.e., the $\mathrm{HCl}$ extract of the heptane-isoamyl alcohol extract of the alkalinized serum) (Shand et al., 1970) was also measured. This $\mathrm{HCl}$ solution, which is normally used for the measurement of fluorescence due to propranolol, contains only propranolol and possibly its basic metabolite(s) (Hayes and Cooper, 1971). The only known basic metabolite of propranolol is $\mathrm{N}$ desisopropylpropranolol (Walle and Gaffney, 1972). Although it was not measured specifically, it is unlikely that this extract contains any 4-hydroxypropranolol. This metabolite is unstable in the extraction procedure (Hayes and Cooper, I97I); it is formed after oral but not after intravenous propranolol (Cleaveland and Shand, 1972; Shand and Rangno, 1972). When $0.2 \mathrm{ml}$ of the $\mathrm{HCl}$ extract was counted in Bray's solution (Bray, 1960) the sensitivity of propranolol determination in subjects treated intravenously with $\mathrm{I} \mathrm{mg}$ of the drug was increased to $\mathrm{I} \mathrm{ng} / \mathrm{ml}$. When the drug was given orally, the specific activity of the administered dose was too low, and this procedure did not enhance the sensitivity of propranolol measurement.

Total plasma radioactivity levels were measured by liquid scintillation spectrometry after digestion of 0.2 $\mathrm{ml}$ aliquots with $2 \mathrm{ml}$ Soluene ${ }^{(R)}$ (a tissue solubilizer obtained from Packard Instrument Co., Downers Grove, Illinois) and addition of $15 \mathrm{ml}$ scintillation fluid comprising 5 g Omnifluor ${ }^{(R)}$ (New England Nuclear Corp., Boston, Massachusetts) per litre of toluene.

Tissue levels Tissue levels of unchanged ${ }^{14} \mathrm{C}$ labelled propranolol and its basic metabolite(s) were measured according to Hayes and Cooper (I97I). Samples (approximately I g) were homogenized in $10 \%$ sodium carbonate solution. The homogenate was mechanically shaken for 20 minutes with ro $\mathrm{ml}$ toluene. After centrifugation at $2000 \mathrm{rev} / \mathrm{min}$ for Io minutes $5 \mathrm{ml}$ of the toluene layer was added to ro $\mathrm{ml}$ toluene phosphor solution of 3/2 normal strength, and counted. Since this procedure may (Hayes and Cooper, I97r) or may not (D. M. Foulkes, 1973, personal communication) extract small amounts of 4-hydroxypropranolol, the relevant data in Tables 2 and 4 (which have been expressed as ng unchanged propranolol/g tissue) represent maximum values for unchanged tissue propranolol levels.

Tissue total radioactivity levels were measured after digestion of duplicate $50-100 \mathrm{mg}$ aliquots in Soluene. After addition of scintillation fluid, samples were placed in the dark for 24 hours to minimize chemiluminescence and counted until successive counts were stable.

The limits of sensitivity of radioactivity measurements in serum and tissue are presented in Table $r$.

\section{Results}

In patients who had received propranolol chronically preoperatively (Group I) the fluorescence assay for propranolol failed to detect differences in fluorescence of plasma or atria between control patients and those in whom the drug had been discontinued 24 to 72 hours before surgery (B). These findings indicate that less than $10 \mathrm{ng} / \mathrm{ml}$ was present in the plasma. The isoprenaline dose-contractile response curve obtained in atria from patients 24 to 72 hours after discontinuation of propranolol was similar to that of control atria (Fig. I). Thus there was neither 
TABLE I Limit of sensitivity of radioactivity measurements

\begin{tabular}{|c|c|c|c|c|c|c|}
\hline \multirow{3}{*}{$\begin{array}{l}\text { Route of } \\
\text { administration }\end{array}$} & \multicolumn{2}{|l|}{ Dose } & \multicolumn{4}{|c|}{ Sensitivity } \\
\hline & \multirow[t]{2}{*}{$\mu C i$} & \multirow[t]{2}{*}{$m g$} & \multicolumn{2}{|c|}{ Total radioactivity } & \multicolumn{2}{|c|}{${ }^{14} C$ propranolol } \\
\hline & & & $\begin{array}{l}\text { Plasma } \\
(n E q / m l)\end{array}$ & $\begin{array}{l}\text { Tissue } \\
(n E q / g)\end{array}$ & $\begin{array}{l}\text { Plasma } \\
(n g / m l)\end{array}$ & $\begin{array}{l}\text { Tissue } \\
(n g / g)\end{array}$ \\
\hline I.V. & 25 & I & 0.003 & 0.03 & $\mathbf{I}$ & 0.3 \\
\hline Oral & 25 & $4 I$ & 0.13 & 1.00 & 40 & 15 \\
\hline Oral & 75 & 43 & 0.05 & 0.03 & 15 & 5 \\
\hline
\end{tabular}

* Limits derived from the following sensitivities: $50 \mathrm{dpm} / \mathrm{ml}$ plasma for both total radioactivity and ${ }^{14} \mathrm{C}$ propranolol, $400 \mathrm{dpm}$ total radioactivity/g tissue, and $20 \mathrm{dpm}{ }^{14} \mathrm{C}$ pro$\mathrm{pranolol} / \mathrm{g}$ tissue. Differences in sensitivity for estimations from plasma and tissue are due to differences in sample size and extent of quenching.

chemically measurable propranolol nor evidence of pharmacological activity of either propranolol or possible active metabolites.

Plasma radioactivity and propranolol levels of Group 2 patients who had received $\mathrm{I} \mathrm{mg}$ of ${ }^{14} \mathrm{C}$ labelled propranolol intravenously are shown in Fig. 2. Unchanged propranolol levels were too low to be detected by fluorescence (sensitivity $10 \mathrm{ng} / \mathrm{ml}$ ), but were above the level of sensitivity for radioactivity measurements (sensitivity I $\mathrm{ng} / \mathrm{ml}$ ). The serum half-life varied between 1.5 and 5 hours.

Table 2 shows the total tissue radioactivity and the toluene-extractable radioactivity (representing propranolol) from these same Group 2 patients. In three of the four patients there were only small

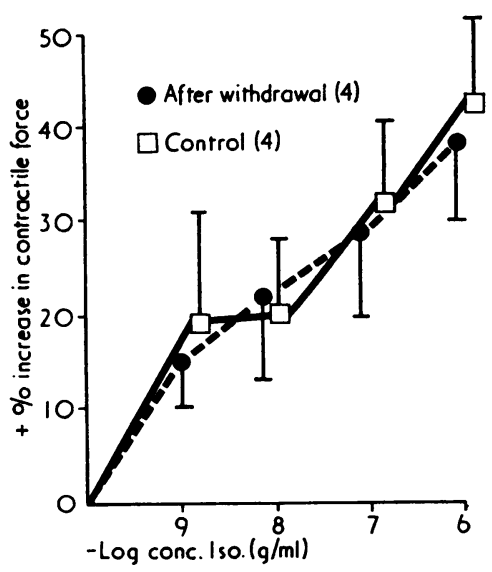

FIG. I Percent. increase in peak contractile force (mean \pm S.E.) following isoprenaline in vitro in human atria from four control patients who had not received propranolol $(\square)$ and from four patients in whom propranolol had been withdrawn prior to surgery (O). amounts of unchanged propranolol in the myocardium by Io hours. Such low levels would appear to be below the pharmacologically demonstrable threshold for beta blockade, since both the chronotropic and inotropic indices measured in vivo had returned to control levels by $6 \frac{1}{2}$ hours in the two Group 2 patients studied by noninvasive techniques. No radioactivity was found in skeletal muscle or in adipose tissue except in one patient.

Table 3 shows the plasma radioactivity levels after

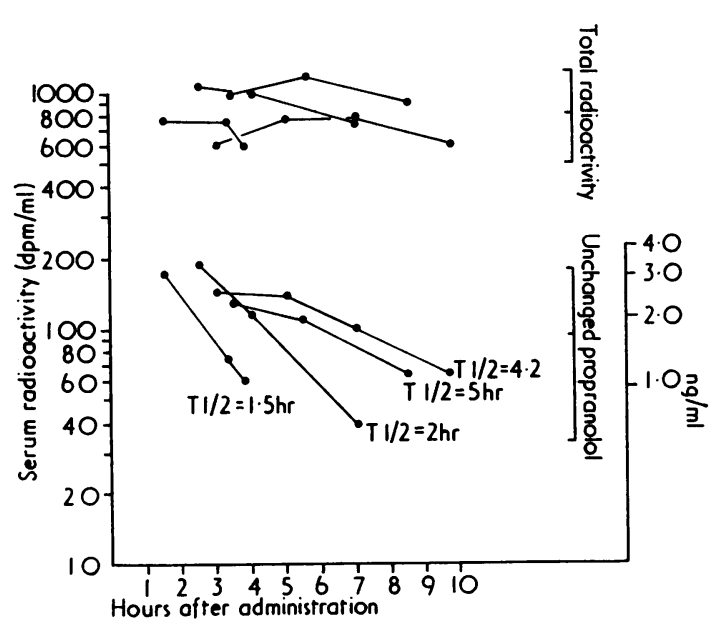

FIG. 2 The plasma total radioactivity in four patients in Group 2 who received $\mathrm{I}$ mg ${ }^{14} \mathrm{C}$ propranolol intravenously are represented in the four upper curves. The radioactivity in the $\mathrm{HCl}$ extract of heptane-isoamyl alcohol extract of alkalinized serum, representing unchanged propranolol, is shown by the lower curves. The radioactivity of this extract converted to plasma propranolol concentration $(\mathrm{ng} / \mathrm{ml})$ is represented on the right ventricle scale. Plasma halflife for each patient is indicated. 
TABLE 2 Total and toluene extractable radioactivity in tissues of patients after intravenous administration of I $m g{ }^{14} \mathrm{C}$ propranolol $(25 \mu \mathrm{Ci})$

\begin{tabular}{|c|c|c|c|c|c|c|c|c|c|c|c|}
\hline \multirow[t]{3}{*}{ Patient } & \multirow{3}{*}{$\begin{array}{l}\text { Time } e^{\star} \\
\text { (hours) }\end{array}$} & \multicolumn{4}{|c|}{ Total radioactivity $(n E q / g) \dagger$} & \multicolumn{6}{|c|}{ Unchanged propranolol $\ddagger$} \\
\hline & & \multirow{2}{*}{$\begin{array}{l}\text { Left } \\
\text { ventricle }\end{array}$} & \multirow{2}{*}{$\begin{array}{l}\text { Right } \\
\text { atrium }\end{array}$} & \multirow{2}{*}{$\begin{array}{l}\text { Skeletal } \\
\text { muscle }\end{array}$} & \multirow{2}{*}{$\begin{array}{l}\text { Adipose } \\
\text { tissue }\end{array}$} & \multicolumn{2}{|c|}{ Left ventricle } & \multirow{2}{*}{$\begin{array}{l}\text { Right } \\
\text { atrium } \\
n E q / g\end{array}$} & \multirow{2}{*}{$\begin{array}{l}\text { Skeletal } \\
\text { muscle } \\
n E q / g\end{array}$} & \multicolumn{2}{|c|}{ Adipose tissue } \\
\hline & & & & & & $n E q / g$ & $n g / g$ & & & $n E q / g$ & $n g / g$ \\
\hline A & 10 & 0.095 & 0.048 & 0 & 0 & 0.024 & $7 \cdot 3$ & $\circ$ & $\circ$ & 0 & 0 \\
\hline B & 8 & 0.062 & 0.027 & 0 & 0.073 & 0.018 & 5.3 & $\circ$ & $\circ$ & 0.007 & 2.2 \\
\hline C & 4 & 0 & 0 & 0 & 0 & 0 & 0 & 0 & 0 & 0 & 0 \\
\hline D & 9 & 0.073 & 0.040 & 0 & 0 & 0.008 & 2.3 & 0 & 0 & 0 & 0 \\
\hline
\end{tabular}

* Time indicates interval from intravenous administration of drug to removal of tissue.

† NanoEquivalents per gram provide an estimate of propranolol and total metabolites independent of changes in molecular weight produced by metabolism of the parent compound.

¥ Toluene extractable radioactivity.

oral administration of ${ }^{14} \mathrm{C}$-labelled propranolol 24 to 95 hours preoperatively (Group 3 patients). While levels of total radioactivity representing propranolol metabolites were measured, no radioactivity was detected in the $\mathrm{HCl}$ extract of heptane-isoamyl alcohol extract of the alkalinized serum of patients receiving $25 \mu \mathrm{Ci}$ (4I mg) ${ }^{14}-\mathrm{C}$-labelled propranolol orally (Table $3 \mathrm{~A}$ ), thus indicating an apparent absence of unchanged propranolol. Neither was any unchanged propranolol detected fluorometrically in this $\mathrm{HCl}$ extract. In two patients, $75 \mu \mathrm{Ci}(43 \mathrm{mg})$

TABLE 3A Plasma radioactivity levels after oral administration of $25 \mu \mathrm{Ci}$ (4I $\mathrm{mg}){ }^{14} \mathrm{C}$ propranolol

\begin{tabular}{lccl}
\hline Patient & $\begin{array}{l}\text { Time of } \\
\text { sampling }(h)\end{array}$ & $\begin{array}{l}\text { Total plasma } \\
\text { radioactivity }\end{array}$ \\
\cline { 3 - 4 } & & dpm/ml & $n E q / m l$ \\
\hline E & 2 & 1430 & 3.58 \\
& 5 & 940 & 2.35 \\
F & 24 & 0 & 0 \\
& 1.5 & 650 & 1.62 \\
& 5 & 900 & 2.25 \\
& 21 & 700 & 1.75 \\
& 50 & 490 & 1.22 \\
& 69 & 250 & 0.62 \\
& 74 & 0 & 0 \\
G & 95 & 0 & 0 \\
& 2 & 920 & 2.30 \\
& 22 & 90 & 0.23 \\
H & 45 & 0 & 0 \\
& 1 & 940 & 2.35 \\
& 15 & 410 & 1.02 \\
& 20 & 230 & 0.57 \\
& 37 & 0 & 0 \\
& & &
\end{tabular}

^ No unchanged propranolol was detected in these samples. propranolol was given in order to increase the sensitivity of the measurements. Extremely low levels of unchanged propranolol were detected in the plasma (Table $3 \mathrm{~B}$ ). In one patient ( $\mathrm{J}$ ) the plasma disappearance rate of total radioactivity and unchanged propranolol appeared prolonged, but only two samples were analysed from this patient, and possible circulatory abnormalities may have caused this effect. Moreover, in this patient the chronotropic and inotropic responses to isoprenaline had returned to control levels by $7 \frac{1}{2}$ hours after dosing. Table 4 shows the tissue radioactivity in the Group 3 patients who received propranolol orally. No radioactivity was detected in any of the tissue samples obtained in patients receiving $25 \mu \mathrm{Ci}$. In patients $\mathrm{I}$ and $\mathrm{J}$, who received $75 \mu \mathrm{Ci}$, small amounts of propranolol were detected in the myocardium in one patient and in adipose tissue of both. The pharmacological measurements suggest that these low levels which we detected only with higher doses of ${ }^{14} \mathrm{C}$-labelled propranolol were not pharmacologically active.

TABLE 3B Plasma radioactivity and propranolol levels after oral administration of $75 \mu \mathrm{Ci}$ (43 mg) ${ }^{14} \mathrm{C}$ propranolol

\begin{tabular}{llllll}
\hline Patient & $\begin{array}{c}\text { Time of } \\
\text { sampling }(h)\end{array}$ & $\begin{array}{l}\text { Total plasma } \\
\text { radioactivity }\end{array}$ & $\begin{array}{l}\text { Unchanged } \\
\text { propranolol }\end{array}$ \\
\cline { 3 - 6 } & & dpm/ml & $n E q / m l$ & $n E q / m l$ & $n g / m l$ \\
\hline I & 3 & 4800 & 4.10 & 0.07 & 19 \\
& 8 & 1580 & 137 & 0 & 0 \\
J & 29 & 170 & 0.15 & 0 & 0 \\
& 4 & 2520 & 2.19 & 0.13 & 38 \\
& 28 & 2120 & 1.85 & 0.05 & 15 \\
\hline
\end{tabular}


TABLE 4 Total and toluene extractable radioactivity in tissues of patients after oral administration of ${ }^{14} \mathrm{C}$ propranolol

\begin{tabular}{|c|c|c|c|c|c|}
\hline \multirow[t]{2}{*}{ Patient } & \multirow{2}{*}{$\begin{array}{l}\text { Time of } \\
\text { sampling } \\
(h)\end{array}$} & \multirow[t]{2}{*}{ Tissue } & \multicolumn{2}{|l|}{$n E q / g$} & \multirow{2}{*}{$\begin{array}{l}\text { Propranolol } \\
\text {-levels } \\
\text { (ng/g)† }\end{array}$} \\
\hline & & & $\begin{array}{l}\text { Total } \\
\text { radioactivity }\end{array}$ & $\begin{array}{l}\text { Unchanged } \\
{ }^{14} \mathrm{C} \text { propranolol }\end{array}$ & \\
\hline \multirow[t]{3}{*}{$I^{\star}$} & \multirow[t]{3}{*}{28} & Left ventricle & 6.60 & 0.09 & 30 \\
\hline & & Adipose tissue & 1.74 & 1.00 & 290 \\
\hline & & Skeletal muscle & 0 & 0 & 0 \\
\hline \multirow[t]{3}{*}{$J^{\star}$} & \multirow[t]{3}{*}{29} & Left ventricle & 0 & 0 & 0 \\
\hline & & Adipose tissue & 0.93 & 0.05 & 15 \\
\hline & & Skeletal muscle & 0 & 0 & 0 \\
\hline \multirow[t]{4}{*}{$\mathbf{E}$} & \multirow[t]{4}{*}{24} & Left ventricle & 0 & 0 & 0 \\
\hline & & Right atrium & 0 & 0 & 0 \\
\hline & & Adipose tissue & 0 & $\delta$ & 0 \\
\hline & & Skeletal muscle & 0 & 0 & 0 \\
\hline \multirow[t]{4}{*}{ F } & \multirow[t]{4}{*}{95} & Left ventricle & 0 & 0 & 0 \\
\hline & & Right atrium & 0 & 0 & 0 \\
\hline & & Adipose tissue & 0 & 0 & 0 \\
\hline & & Skeletal muscle & 0 & 0 & 0 \\
\hline \multirow[t]{4}{*}{ G } & \multirow[t]{4}{*}{45} & Left ventricle & 0 & 0 & 0 \\
\hline & & Right atrium & 0 & $\circ$ & 0 \\
\hline & & Adipose tissue & 0 & 0 & 0 \\
\hline & & Skeletal muscle & 0 & 0 & 0 \\
\hline \multirow[t]{3}{*}{$\mathbf{H}$} & \multirow[t]{3}{*}{37} & Left ventricle & 0 & 0 & 0 \\
\hline & & Adipose tissue & 0 & 0 & 0 \\
\hline & & Skeletal muscle & 0 & 0 & 0 \\
\hline
\end{tabular}

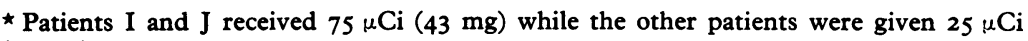
(4I mg).

† Toluene extractable radioactivity.

\section{Discussion}

Information on the appropriate time to discontinue drug before operation is an obvious need for a drug in general use, but the limitations in undertaking an ethical and controlled study in man are not always appreciated. Physiological and pharmacological measurements, even when undertaken in patients, must of necessity be indirect and substitute for the clinical situation. However, a clinical pharmacological approach offers an opportunity to obtain a more critical evaluation of factors thought to be important in the complicated and multifactorial experience during and after operation. Biochemical and/or radiochemical techniques offer an opportunity to identify and quantify the drug substance and/or metabolites, but these parameters should be combined with biological activity measurements to be most meaningful. Information on an appropriate period for discontinuing propranolol is needed, but relevant studies, particularly in those patients who are to undergo cardiac surgery, are difficult to execute. The principal pharmacological activity -i.e. blockade of beta receptors - could interfere with sympathetic responses needed postoperatively, and many physicians would choose to withdraw the drug preoperatively. This could leave the patient un- protected against various stresses if surgery is scheduled only after some days or weeks. On the other hand, sudden discontinuance of therapy has produced rebound attacks of unstable coronary artery disease (Slome, 1973; Alderman et al., 1974; Mizgala and Counsell, 1974), and two reports (Jones et al., 1974; Levenson et al., 1974) suggest that cardiac surgery without discontinuing propranolol may be the treatment of choice.

In our studies we have approached the problem by making associated pharmacological and biochemical measurements in cardiac patients. The choice to measure residual beta blockade in isolated atrial tissue or in intact man is reasonable, since the other actions of this drug or its metabolites occur only with higher doses, e.g. - quinidine-like activity or are associated with shorter half-life metabolites e.g., 4-hydroxypropranolol (Paterson et al., 1970; Fitzgerald and O'Donnell, I97I) - and each of these would be less important in the 24-48-hour period after discontinuance of the drug when levels are low. Initial studies began with simple chemical fluorescent measurements for propranolol in serum or atria, in patients who had been receiving the drug chronically, and we included tests on the antagonism of isoprenaline in isolated organ baths. We failed to 
see any difference between control and propranolol patients, and these findings are consistent with reports by Faulkner et al. (1973). This latter report was published after our studies were completed.

Next, we administered single doses of ${ }^{14} \mathrm{C}$-labelled propranolol intravenously or orally and then increased the dose of radioactivity to increase measurement sensitivity. Because we emphasized tissue radioactivity determinations, the number of studies which could be undertaken was limited, and the time of measurements was varied to screen for possible effects. We demonstrated levels of radioactive metabolites in human tissue, and this was expected from previous animal studies (Hayes and Cooper, 1971; Masuoka and Hansson, 1967), which measured tissue levels, and from a clinical study (Paterson et al., 1970) which measured serum levels of propranolol and radioactive metabolites. Little or no unchanged propranolol was detected even when $75 \mu \mathrm{Ci}$ of propranolol was administered, and then myocardial levels were below the levels which evidently could have affected chronotropic or inotropic responses to isoprenaline. The radioactive data from this clinical study are of necessity from administration of single doses, but they do support the observation that the principal drug effects (beta blockade) and tissue residues of pharmacological importance have virtually disappeared by 24 to 48 hours. Neither we nor others (Faulkner et al., 1973) could find evidence for dissociation of the effect of propranolol given chronically on the chronotropic and inotropic responses to isoprenaline as reported by Robinson, Rich, and Weissler (1973). Levenson et al. (1974) reported that while the haemodynamic effects of repeat-dose propranolol given to normal volunteers were dissipated by 72 hours after the last dose, in the immediate period after withdrawal of propranolol, haemodynamic effects persisted when blood levels had dropped. However, this study did not determine the complete dose-effect curve for the blood level-haemodynamic effect relationship and did not study the kinetics of both the pharmacological and biochemical measurements. Our conclusions are consistent with the recommendation made by Faulkner et al. (1973) from the results of their combined animal and human studies, though these studies did not include ${ }^{14} \mathrm{C}$-labelled propranolol administration nor human tissue level measurement.

This study was principally designed to determine the period necessary for dissipation of propranolol itself and its beta blockade in order to recommend a safe period for withdrawal. However, we would note that many (Slome, 1973; Mizgala and Counsell, 1974), including ourselves (Alderman et al., 1974), have reported that abrupt withdrawal of pro- pranolol in some patients with severe coronary artery disease or unstable angina pectoris can cause rebound angina and even myocardial infarction. This complication appears to be related to diminished drug effects leaving the myocardium unprotected against stress, rather than from residual drug and continued pharmacological effects of propranolol. The recommendation for safe withdrawal should direct the physician to observe the patient closely for rebound and to be prepared to reinstitute drug therapy if deemed advisable. Under emergency situations in patients receiving propranolol it may be undesirable to withdraw the drug. Moran et al. (1973) and Jones et al. (1974) suggest that appropriately selected patients receiving propranolol throughout cardiac surgery may be at no greater risk than patients who had not received the drug. After completion of this study we retrospectively compared two consecutive series of roo patients, each of whom had undergone elective vein bypass cardiac surgery for angina pectoris at Stanford University. In patients who had not received propranolol in the medical management of their symptoms before operation the average mortality was 5 per cent. In the series in which propranolol had been discontinued I to Io days before surgery the mortality was 3 per cent. While this survey could not be considered definitive, the results are consistent with the Vanderbilt experience noted by Faulkner et al. (1973) and tend to refute the report by Viljoen et al. (1972). A large, controlled series in which propranolol was or was not withdrawn before surgery, using a random selection process, could clarify the issues but would be difficult to undertake.

In conclusion, since propranolol is used for symptomatic relief in patients with angina pectoris rather than for a direct effect on underlying disease processes, it would seem logical to discontinue a drug with known negative inotropic effects before undertaking elective cardiac surgery. However, withdrawal may result in rebound angina and possibly myocardial infarction in some patients. The decline of the blockade of isoprenaline's chronotropic and inotropic activity, together with the measurement of unchanged ${ }^{14} \mathrm{C}$-labelled propranolol, indicates that 24 to 48 hours is a conservative estimate for a satisfactory withdrawal. This period of time would often conveniently coincide with the preoperative admission time of the patient, when the drug can safely be withdrawn or dosage reduced while the patient is carefully observed for possible recurrence of severe angina pectoris.

\section{References}

Alderman, E. L., Coltart, D. J., Wettach, G. E., and Harrison, D. C. (1974). Coronary artery syndromes resulting from 
sudden propranolol withdrawal. Annals of Internal Medicine, 81, 625 .

Bray, G. A. (1960). A simple efficient liquid scintillator for counting aqueous solutions in a liquid scintillation counter. Analytical Biochemistry, I, 279.

Cleaveland, C. R., Rangno, R. E., and Shand, D. G. (1972). A standardized isoproterenol sensitivity test. Archives of Internal Medicine, 130, 47.

Cleaveland, C. R., and Shand, D. G. (1972). Effect of route of administration on the relationship between $\beta$-adrenergic blockade and plasma propranolol level. Clinical Pharmacology and Therapeutics, 13, 181.

Coltart, D. J., and Shand, D. G. (1970). Plasma propranolol levels in the qualitative assessment of $\beta$-adrenergic blockade in man. British Medical fournal, 3, 731.

Coltart, D. J., and Spilker, B. A. (1972). Development of human foetal inotropic responses to catecholamines. Experientia, 28, 525.

Faulkner, S. L., Hopkins, J. T., Boerth, R. C., Young, J. L., Jr., Jellet, L. B., Nies, A. S., Bender, H. W., and Shand, D. G. (1973). Time required for complete recovery from chronic propranolol therapy. New England fournal of Medicine, 289, 607.

Fitzgerald, J. D., and O'Donnell, S. R. (1971). Pharmacology of 4-hydroxy-propranolol, a metabolite of propranolol. British Fournal of Pharmacology, 43, 222.

Hayes, A., and Cooper, R. G. (197I). Studies on the absorption, distribution and excretion of propranolol in rat, dog and monkey. Fournal of Pharmacology and Experimental Therapeutics, 176, 302.

Jones, E. L., Dorney, E. R., King, S. B., Gray, B. T., and Hatcher, C. R. (1974). Propranolol therapy in patients undergoing myocardial revascularization. Circulation, 50, Suppl. III, III-I I2.

Levenson, L. W., Leaman, D. M., Babb, J. D., Zelis, R., and Hayes, A. H. (1974). Propranolol: disparity between hemodynamic actions and biological half-life. Circulation, 50, Suppl. III, III-78.

Masuoka, D., and Hansson, E. (1967). Autoredisgraphic dis- tribution studies of adrenergic blocking agents: II, ${ }^{14} \mathrm{C}$ propranolol, a beta-receptor-type blocker. Acta Pharmacologica et Toxicologica, $25,447$.

Mizgala, H. F., and Counsell, J. (1974). Acute coronary syndromes following abrupt cessation of oral propranolol therapy. Circulation, 50, Suppl. III, III-33

Moran, J. M., Mulet, J., Caralps, J. M., and Pifarre, R. (1973). Coronary revascularization in patients receiving propranolol. Circulation, 50, Suppl. II, II-I I6.

Paterson, J. W., Conolly, M. E., Dollery, C. T., Hayes, A., and Cooper, R. G. (1970). The pharmacodynamics and metabolism of propranolol in man. Pharmacologia Clinica, 2, 127.

Robinson, J. S., Rich, J. M., and Weissler, A. M. (1973). Differential effects of propranolol on the chronotropic and inotropic response to isoproterenol in man. American fournal of Cardiology, 31, 155.

Shand, D. G., Nuckolls, E., and Oates, J. A. (1970). Plasma propranolol levels in adults, with observations in four children. Clinical Pharmacology and Therapeutics, II, I12.

Shand, D. G., and Rangno, R. E. (1972). The disposition of propranolol. Pharmacology, 7, 159.

Slome, R. (1973). Withdrawal of propranolol and myocardial infarction. Lancet, I, I56.

Vilioen, J. F., Estafanous, G., and Kellner, G. A. (1972). Propranolol and cardiac surgery. Fournal of Thoracic and Cardiovascular Surgery, 64, 826.

Walle, T., and Gaffney, T. E. (1972). Propranolol metabolism in man and dog: mass spectrometric identification of six new metabolites. Fournal of Pharmacology and Experimental Therapeutics, 182, 83.

Weissler, A. M., Harris, W. S., and Schoenfeld, C. D. (1968). Systolic time intervals in heart failure in man. Circulation, 37, 149.

Requests for reprints to Professor Donald C. Harrison, Cardiology Division, Stanford University School of Medicine, Stanford, California 94305, U.S.A. 